\title{
A Research on Possibility and Paths of Social Participation in Ideological and Political Education at Colleges
}

\author{
Qiaobin Huang ${ }^{1}$, Xiaodong $\mathrm{Ru}^{1}$ \\ ${ }^{1}$ Law School, Fuzhou University, Fuzhou, 350116, China
}

Keywords: College students. Ideological and political education. Social participation

\begin{abstract}
Higher education develops towards a popular style, social informatization deepens, and school-running mode of colleges walk towards openness. As a result, participation of all kinds of social factors in colleges' management will become a trend undoubtedly. Such a trend is reflected by the field of colleges' ideological and political education naturally. Under the situation that this thesis has mastered this kind of school-running with informatization and openness, it analyzes possibility of social participation in colleges' ideological and political education and tries to explore several good methods of social participation in practice.
\end{abstract}

\section{Introduction}

Colleges' ideological and political education obviously shows the systematic feature that college, society and family are 'trinity', which requires that colleges' ideological and political education should not only be established in its own perfection and development but also explore all kinds of possibilities and methods of social participation and work hard to construct social participation mechanism of colleges' ideological and political education. This is a problem that is worth attaching importance to and studying.

\section{The basis on which social participation mechanism of colleges' ideological and political} education occur

The reason why social participation mechanism of colleges' ideological and political education can occur is that this situation is decided by systematic feature, educational function and development direction of colleges' ideological and political education.

Systematic feature of colleges' ideological and political education and social participation mechanism is an inevitable requirement of social participation in colleges' ideological and political education

Social participation in colleges' ideological and political education means all elements relate to one another in the process of education activities, affect and act on one another in the process of relationship and finish overall objective and overall function of colleges' ideological and political education when colleges' ideological and political education is carried out. The feature of mutual correlation and interaction obviously shows colleges' ideological and political education, which acts as a special system, has its systematic characteristics. At the same time, for the whole social system, it is a component. Thus, it will drive all elements in colleges' ideological and political education to relate to other elements in the social system and interact with one another inevitably. Now that schools and the society show systematicness of correlation and interaction, they will inevitably require that colleges' ideological and political education should promote social development of educational activities and integrate with the society actively in the process of implementation. At the same time, it is required that the society which serves as a large system should provide resources and driving force for colleges' ideological and political education and participate in colleges' ideological and political education actively. Objective function of colleges' ideological and political education can be reflected to the largest extent and the educational goal that colleges aim at cultivating qualified constructers and successors can be realized ultimately only when the two have bilateral interaction with each other favorably. 


\section{The objective function of colleges' ideological and political education is an inevitable choice of social participation in ideological and political education}

Exactly, college students' ideological and political education just involves colleges explore effective approaches of education, guide students to learn, develop and become socialist talent, excellent social members and responsible family members, which is a responsibility and mission of colleges' ideological and political education.

From the perspective of the country, enhancing and promoting college students' ideological and political education, improving their ideological and political quality and cultivating them to become constructers and successors of socialism with Chinese characteristics are of important, profound and strategic significance for our country to implement the strategy of developing the country through science and education and reinvigorating China by human resource development comprehensively, ensure China can remain invincible in fierce international competition all the time, guarantee the grand goal that well-off society in all aspects is built and socialist modernization is accelerated can be realized and ensure socialist cause with Chinese characteristics can flourish and have qualified successors. From this perspective, it will inevitably require that central government and all local governments should pay much attention to college students' ideological and political education, which provides possibility for social participation in colleges' ideological and political education.

From the perspective of the society, college students not only undertake the responsibility to be natural successors of social extension but also are asked to become pioneers of social development as well as the most important reserve force of technical innovation, renewal of ideas and development of social productivity. College students' socialized quality and degree during their college life not only relate to whether their life and career can be successful or not after they have entered the society but also have relationship with social development. This requires that colleges must impart socialist core values, especially the ones in social environment, to students' brain by various methods when they promote college students' learning development in order to make students integrate with social mainstream in the aspects of civic awareness, political and legal consciousness and moral consciousness in the process of interaction with the society. In this way, college students will not only be accepted by the society but also become driving force promoting social development, construction of harmonious society as well as reform and innovation. This provides social environment where college students take part in the society and the society participates in colleges' ideological and political education.

From the perspective of families, college students' ideological and political education relates to both development of the country and the society and vital interests of all college students' family. Effectiveness of colleges' ideological and political education will inevitably affect the family that acts as a basic unit of the society and relate to vital interests of all families. Thus, enhancement and improvement in college students' ideological and political education are a 'popularity-winning' project that implements Scientific Outlook on Development and runs satisfying education for people. This project will draw much attention and expectation from students' parents undoubtedly, which provides powerful driving force for intervention of the factor family in social participation in ideological and political education.

\section{Path selection of mechanism about social participation in colleges' ideological and political education}

Occurrence of social participation in colleges' ideological and political education is a product of the trend that ideological and political education walks towards socialization and a requirement of reform and development of colleges' ideological and political education. This inevitably requires that colleges should explore main paths about social participation in ideological and political education. Several paths that the author considers to be important will be introduced simply in the following content. 


\section{Path 1 about social participation in colleges' ideological and political education: carrying out innovation for social practice and improving effectiveness of social practice}

Since college students' social practice was developed, its importance has been realized by all teachers and students jointly. Up to now, it has come to a stage where innovation is carried out for service, and long-term effectiveness and timeliness are improved. With respect to how to exert effect of social practice in colleges' ideological and political education, the author deems that we should focus on solving the following problems.

Center on solving the problem about all people's involvement in social practice.

Colleges' social practice still stays under the situation that groups are organized intensively during holidays and proportion of the number of teachers and students who participate is still low. For this problem and from the perspective of schools, it is required that all colleges should implement profound researches, propose countermeasures, organize key practice groups to exert resource advantages intensively and ensure all college students have sufficient chances to take part in social practice as well. From the perspective of teachers, it is required that all teachers and courses should promote social practical activities consciously and exert the effect that teachers can guide and lead students in social practice. From the perspective of students, they should exert their subjectivity fully and college students ought to take part in social practice actively and consciously rather than stay at the precious mode of social practical activities, i.e., 'waiting, relying and asking'. Moreover, conscious acceptance of social practice should become a kind of self-awareness, by which modern college students can realize self-accomplishment.

Focus on solving social participation of social practice.

On the one hand, the said participation of social practice requires that college students should 'go deep into, learn and serve the society', practice themselves in practice and achieve growth by practice. On the other hand, the society need provide resources and help for college students' social practice actively. All social circles should realize significance of social practice for college students and take part in it actively. This requires that we ought to overcome formalistic trend in design of college students' social practice activities. In the aspect of work, we should make careful arrangement and elaborate assignment to achieve students' welcome and the society's approval. Meanwhile, we must work hard, broaden channels and make all social circles provide service and help for college students' social practice.

\section{Concentrate on solving institutional nature of social practice.}

Being restricted by all kinds of factors, planning and institutional nature of arrangement about social practical activities are insufficient, which is mainly reflected by the following aspects. Firstly, time arrangement of activities is random, which mainly means holidays are arranged freely. Secondly, construction of social practice lacks continuity and durability, i.e., social practice usually changes its places and long-term connection with corresponding units is lacked. Thirdly, except for key groups organized by schools, few students who practice alone do not implement social practice consciously, some of them even muddle by counterfeit certification. Besides, omission exists in teachers' guidance for practice and there is obvious difference among different teachers. It is necessary for schools to study all of these problems, establish scientific management, assessment and evaluation system, solve the problem according to system and mechanism and provide institutional guarantee for effectiveness and long-term effect of social practice.

Path 2 about social participation in colleges' ideological and political education: constructing family-school interaction and looking for new resources of social participation

Family education is an important aspect of development of students' moral quality. Construction of family-school cooperative educational platforms and formation of educational resultant force are new approaches and methods when we face with severe challenges under the new situation. The author deems we should focus on solving the following three problems.

\section{Center on solving concept of family-school interaction.}

First of all, we should change our opinions, alter the practice that colleges' ideological and political education fights alone, establish the educational idea that school, society and family are 'trinity' ideally and sufficiently realize that students' growth and achievement are a common goal of 
families and schools as well as a bond of family-school cooperation, and families and schools play irreplaceable in college students' ideological and political education. Thus, colleges' ideological and political education should create conditions, enhance communication and cooperation between families and schools actively and build interactive platforms. Based on bilateral interaction, families and schools should keep consistent goals, coordinate paces, realize resource complementation, cooperate with each other and form good resultant force.

Concentrate on solving effectiveness of family-school interaction.

Effective forms of family-school are important guarantee by which family-school cooperation can be realized. Colleges should explore it actively and establish various effective forms, such as they may establish a common parent committee, build long-term and effective mechanism about connection between parents and schools and among parents, exert advantages of new media, set up network communication platforms like WeChat and QQ group, and obtain space for family-school interaction and shorten spatial distance between families and schools by virtue of convenience provided by network. In addition, colleges may establish parent resource pools, arouse parents' strengths in the aspects of professional specialty and social contact resources and inject new resources into colleges' ideological and political education by providing conditions for social practice and personal participation in colleges' ideological and political education etc. Via all of these effective forms, we should work hard to explore harmonious and interactive mechanisms about family-school cooperation and exert resultant action of family-school cooperation.

Path 2 about social participation in colleges' ideological and political education: using network platforms and adapting to new requirements of reform and development

Facing with all kinds of changes brought by network and mobile phone media, colleges' ideological and political education should make full use of resources an approaches resulted from this, cope with various new challenges, utilize network platforms fully and expand new approaches of ideological and political education. For this, the author also thinks that we should work hard in three aspects similarly.

\section{Focus on solving and using initiative of network platforms.}

Facing with network that changes and develops sharply and culture generated by it, we should meet challenges actively, cope with this positively, adapt to and make full use of its advantages actively, realize and use socialized functions of ideological and political education in network culture sufficiently, enhance the consciousness that we should use Marxism to occupy ideological and cultural front of colleges further, improve our cognition about significance and urgency of the situation that ideological and political education enters network, launch an active attack, make specific planning and uniform deployment for the situation that ideological and political education enters network and uses network to serve ideological and political education as soon as possible, add content of ideological and political education and expand space and channel of ideological and political education.

\section{Center on solving and using associativity of network platforms.}

Making full use of network resources does not mean that we should establish a group of network force simply and ask them to fight alone on the internet. Instead, we should drive two on-line and off-line groups to coordinate with each other and promote each other, focus on themes and main directions and enable socialist core values to affect and guide the young generation by their respective methods. We can realize the new pattern of ideological and political education, i.e., 'paying attention to both inside and outside of network and do the two aspects well simultaneously', and open a new situation of ideological and political education only when on-line and off-line groups coordinate with each other.

\section{Acknowledgments}

This thesis is a common task of 'the 12th Five-Year' plan in educational science of Fujian Province in 2013 (task No.: FJJKCG13-162). 


\section{References}

[1] Fan Fanghong: On Connotation and Occurrence Basis of Mechanism about Social Particiaption in Colleges’ Ideological and Political Education. Journal of Zunyi Normal College, 2012(30:95-97.

[2] Liao Yuewen: A Survey on Ensuring All College Students Can Participate in Social Practice - All College Students Take Part in Social Practice. Journal of Ideological \& Theoretical Education, 2011(1):111-115.

[3] Jiang Enlai: College Students' Ideological and Political Education Under the Background of New Media. Theoretical Front in Higher Education, 2009(6):54-57. 